\title{
A comparative case-study of school-LEA-NGO interactions across different socio-economic strata in Israel
}

\begin{abstract}
This study examines the interaction between NGOs, the Local Education Authority (LEA), and public schools in communities of different socioeconomic backgrounds in Israel. We characterize how schools serving more and less affluent communities create, cultivate, and preserve interactions with NGOs; how NGOs form, and sustain interactions with schools serving communities of different socioeconomic backgrounds, and how this process is maintained through LEA regulation. The methodology is based on qualitative research principles involving data collection by means of in-depth interviews with different stakeholders including school principals, involved teachers, LEA representatives, and NGO directors and staff members. We show how school-NGO-LEA interaction is largely shaped by the affluence of respective schools' communities within given educational settings. Analysis of interviews conducted with different stakeholders exposed two main themes: (1) the differing capabilities of various actors in this interaction to express agency; (2) the power relations between involved parties, whereby NGO and LEA agents impose a global agenda on local schools (particularly those serving less affluent communities) - occasionally in contrast to the needs as perceived by school agents. Our conclusions offer unique insights into the nature and possible consequences of the interaction between third-sector organizations and schools serving communities of different socioeconomic backgrounds.
\end{abstract}


"This program was not on my agenda, but I ended up engaging in it...although it comes at a price."

- School principal from a less-affluent community

\section{Introduction}

Educational systems have undergone many fluctuations over the last three decades. They are being transformed substantially following global transformations including increased liberalization of international trade, integration of new technologies in every sphere of life, deregulation of global financial markets, and the retreat of the welfare state (Robertson, Mundy, Verger, \& Menashy, 2012). This era is characterized by multi-dimensional developments, whereby the neoliberal notion that tends to guide social reforms, is interpreted within the context of growing globalization (Edwards, 2014; Verger, Edwards, \& Kosar-Altinyelken, 2014).

The prevalence of neoliberal governance shapes educational policy and practice "around the principles of the marketplace" (Bulkley \& Burch, 2011: 236), introducing concepts such as "private property rights, free trade, consumerism, performance audits, and entrepreneurism" (Bulkley \& Burch, 2011: 236). Such notions have come to be seen as effective means of dealing with the various challenges educational systems face in developed and developing countries. Simultaneously, and perhaps even as part of the same process, public funds invested in education have been substantially reduced, alongside a rise in the regulatory role of the state (Ball, 2007).

Among other changes, the neoliberal policy allowed and even promoted the entry of third sector entities ${ }^{1}$ into community management and educational practices - through decentralizing,

\footnotetext{
${ }^{1}$ We use the terms third sector organizations, non-profits, and NGOs interchangeably in this paper, despite the various minor differences that some scholars attribute to their meaning (i.e., Kamat, 2004).
} 
shrinking states' responsibility, and encouraging inter-governmental cooperation (Rappleye, 2011; Resnik, 2011). The proliferation of non-governmental organizations (NGOs) in the education landscape can be attributed to the tendency of the public enterprises and governments to seek private solutions to public problems (Edwards \& Hulme, 1995) by producing and sustaining partnerships and associations or as described by Kamat (2004:158) "NGOs are seen as fully cognizant rational actors capable of going beyond sectarian interests and acting upon matters of general welfare".

Notably, both low-income countries and many western countries share this recent social and educational reality where NGOs of different kinds and modes of action are proliferating in the educational policy-making and in the provision of education (Gidron et al., 2004). Kamat (2004) claims that NGOs are replacing the state as representatives of democracy - stepping in to respond to the needs of society's underprivileged sectors and thus (deliberately or not) reinforcing the current capitalistic order. Within the field of education in particular, decentralization poses a certain threat to the preservation of the social equality principle. Indeed, decentralization "can widen quality differences between schools, and performance gaps between students, in wealthy and poor areas" (Dyer \& Rose, 2005: 107), given the ability of communities and schools in wealthier areas to purchase or to gain access by other means to more varied, higher-quality educational services. Moreover, the relative fragility of many NGOs (Arnove \& Christina, 1998) threatens the continuity of the services provided to the less affluent schools relying upon their services - especially schools serving marginalized populations.

Having said that, some scholars have argued that the involvement of third sector organizations in educational processes enables greater flexibility and adjustability to the various differing needs of different schools (Woods \& Woods, 2004). Hence, they usually hold a promise to 
improve educational quality by offering new programs adjusted to different populations (e.g., regarding human rights education, see Suarez, 2007; regarding gender education, see Stromquist, 2008) and by providing ongoing innovation and entrepreneurial opportunities (DeStefano \& Moore, 2010).

The growing presence of NGOs within education systems in many countries (Authors, 2014; 2016) raises significant questions regarding the role and involvement of such external organizations in the education system and leads to our research questions in this study. In particular, we explore in depth how NGO-school interactions are created, cultivated, and maintained in localities of different socioeconomic status and how the power relations between different stakeholders in these processes are constructed and shaped. This paper contributes to the discourses of third sector involvement in education and equality on the basis of in-depth, empirical inquiry into the complex and multidimensional interaction between NGOs, schools, and school districts (or Local Education Authorities [LEAs]). We depict how the same interaction occurring in schools within different socio-economic contexts shapes into a different outcome.

We choose to focus our study on Israel as a state which was originally established with a strong social democratic vision. Yet this vision has eroded over the years, and since the 1980s the Israeli Ministry of Education has gradually embraced neoliberal ideas of decentralization and privatization (Addi-Raccah, 2012). Therefore, while still far from fully embracing the British neo-liberal policies, Israel is slowly moving in this direction, showing similar patterns concerning external actors' activities within the public education system.

We begin by providing a theoretical orientation on recent transformations within the education systems. We specifically present the discourse of equality and the role of NGOs within 
this sphere. We then provide context for our case study in Israel, followed by short presentation of the methodology employed. Next, we present and discuss our findings, address their implications, and conclude.

\section{Theoretical Orientation}

\section{Neoliberal governance and NGOs in education}

Government policies based on the principles of neo-liberalism in the age of globalization have led to a drastic reduction of national governments' roles in social spending and in policies related to public well-being (namely, education and health). In education systems, such reforms usually include choice, accountability, standards, and testing, by which the state's role is to specify goals and priorities and evaluate whether or not the various subnational administrative units and even individual schools achieve the desired results (Arnove, 2009). Those changes are commonly discussed as a transformation from government to governance in education policy and policy enactment (Ball, 2009). Likewise, other actors, including NGOs (sometimes complemented by various intergovernmental organizations such as the World Bank, UNESCO, WTO, OECD, and EU), are filling in the vacuum caused by minimized governmental spending and presence.

Conceptually, the term 'non for profit organization' (or, alternatively, 'Non-Governmental Organization' (NGO) or 'third sector organization') refers to any organization external to both the public sector and the private sector, thereby comprising a group of closely interrelated concepts, including foundations and non-profit organizations (Unerman \& O’Dwyer, 2006). Generally speaking, third-sector organizations combine both public and private characteristics: they are non-profit organizations that rely on public resources and therefore are subject to regulation by the public sector; yet simultaneously, they are private organizations with high levels of autonomy and self-governance (Berkovich \& Foldes, 2012). Kamat (2004) mentions the 
common perception of NGOs as organizations that can implement global commitment to "bottom up' development that is not authorized by the state. NGO is a broad term, with many meanings in diverse contexts. NGOs can play a variety of roles; differ in their size, budget, and scope as well as in their goals, interest and external support. Kamat (2004) in his critique of the blurring definitions of NGOs claims (p. 165): "civil society includes the global capital market as well as citizen movements. Further, the lack of distinction between the market, NGOs and citizen's movements implies that the role of each is equally legitimate and important for global governance. As may be apparent, such an all-encompassing definition of civil society seriously limits the power and influence of advocacy NGOs within global governance forums". Indeed, Mark Ginsburg (2008) interprets the acronym 'NGO' as alternately 'New Great Organization' or 'No Good Organization,' referring to the highly disputed image of NGOs in the public sphere and to diverse individual opinions on the subject.

Eden (2012) presents an interesting and in-depth analysis of the relationships between the third sector, the state, and the education system. She claims that the relationship between third sector and the state can take on different forms: (1) relative mutual indifference and minimal interaction; (2) collaboration, whereby each party depends on the other; and (3) mutual conflict and resistance. The forms of interactions are shaped according to the NGOs' missions and activities - ranging from do-goodery complementary with the current hegemony to revolutionary action that undermines the current order. Rappleye (2011) adds to this construct the concept of institutionalization of external influence showing how external organizations affect and shape educational policies in Nepal and elsewhere.

Notably, the number of NGOs in the world has increased since the 1970s and their importance intensified (Boli \& Thomas, 1999; Drori, Meyer, \& Hwang, 2006), while they became 
recognized as highly prominent actors in international and national systems with a presumed strong impact on development and social change (Hoff \& Hickling-Hudson, 2011). Yet despite the ever-growing presence of NGOs in educational and general public spheres - as they wield increasing influence over national economies and politics (Silova \& Steiner-Khamsi, 2008) - the global research on NGOs is limited and narrowly focused (Ilon, 2008). In particular research showed how NGOs are engage with education mostly within developing countries contexts (for example Silova and Khamsi (2008), in conflict ridden areas where NGOs were found to foster and implement global educational reforms (Edwards, 2014), and important contributions were done looking at the role of commercial and intermediate organizations in developed and developing countries (for example Bulkley \& Burch, 2011; Feuerstein, 2001), but scarce empirical evidence exists on the role and function of NGOs in developed countries, especially outside of research stream that is dealing with programs' assessment and monitoring.

\section{NGOs involvement in schools and equality}

The pitfalls of NGOs' involvement in education with regards to unequal development have been thoroughly highlighted in relation to low-income, developing, and post-conflict countries (Klees, 2008; Silova \& Steiner-Khamsi, 2008). Haugh and Kitson (2007) claim that a situation in which the third sector is the main provider of social services is dangerous. The risk stems from geographical inequalities that may develop in service provision, as a result of the unequal dispersion of projects and social organizations. These organizations may also rely too heavily on volunteer personnel, which could harm the quality of service they provide. Berkovich and Foldes 
(2012) reinforce this claim. They argue that the equal distribution of social services in different geographical areas is of great importance to ensure equal access for all communities, especially since the communities themselves are unevenly distributed in these areas. In addition, third sector organizations often fail to achieve the goals they set as a result of administrative constraints and decisions that are forced upon them by donors, international agencies, and governments (Silova \& Steiner-Khamsi, 2008).

Additional study worth mentioning here in is one by Feuerstein (2001) about the effects and implications of the entry of commercial organizations into the education system. While Feuerstein focuses on commercial organizations and does not address third sector ones directly, his findings can be interpreted in the context of the possible effects the introduction of commercial ideas might have on school-NGO interactions as well. He argues that for many schools, cooperation with commercial entities comprises a legitimate way to create additional resources independently and autonomously. On the other hand, this collaboration threatens the essence of public education, since it exposes schools to commercial influences that may affect their goals and values. Notably, in a time of self-management and decentralization, schools struggle with lack of resources - which might harm the quality of education they provide - and the responsibility to produce new resources themselves (as also highlighted through organizational perspective by Edens and Gilsinan (2005)). In this environment, collaboration with external entities becomes an attractive solution. Feuerstein presents findings showing that most school administrators see these collaborations as beneficial, despite possible negative consequences. He also finds that in schools with more students from low socioeconomic backgrounds, principals' views towards commercial ventures are more positive. Therefore, 
schools in communities of lower socioeconomic backgrounds tend to maintain more commercial activities and partnerships with commercial entities.

Rose (2010) also argues that the phenomenon of NGOs establishing themselves as providers of educational services entails the risk that these organizations will begin to charge fees for the services they provide. Although the sums charged might be low, the need for payment may prevent communities of weaker socioeconomic backgrounds from acquiring the same basic services. Moreover, the organizational and managerial characteristics that affect the activities of third sector organizations must be taken into consideration as well. Eikenberry and Kluver (2004) analyze the impact of neoliberal and commercial ideologies on the activities of these organizations. They claim that third-sector organizations are undergoing a transformation involving the rising influence of marketization, in other words NGOs starting to act more like businesses maximizing their self-interest; although this "may be beneficial for the short-term survival needs of nonprofit organizations, it may have negative long-term consequences" ( $\mathrm{p}$. 132). In the same vain, Miraftab (2004) had showed how private-public partnerships (some of which involving NGO partnerships with local communities) have negative effects on the urban poor, being transformed into de-facto privatization of the public good. In this context he claimed (p. 98) "(governments) risk having the state fade after the project formulation, with the result that the power-sharing scenario intended to serve the interests of all partners dwindles into a familiar charade. Like the Trojan Horse, these partnerships might arrive with the promise of a gift but only to further dispossess the poor from their locally mobilized resources".

Kamat (2004) presents theoretical claim on the role of NGOs within the state-civil society interactions. According to him, (p. 171), "In reclaiming the public space as a negotiation between different private interests, the concept of the public good is impossible to identify, let alone 
defend". Following this line of thought, we explore the NGO-school-LEA interaction in specific context, where it is possible to zoom in into the nature of such interaction, occurring in similar way within schools catering to high and low SES populations. By doing so, we unveil the dynamics of such interaction and capture the role of NGOs in relation to equality within public schooling.

\section{The Israeli education system and third sector}

In Israel, as in many countries, the third sector has developed significantly over the past three decades, becoming an important social force (Haski-Leventhal, Yogev-Keren \& Katz, 2012; Katz, Gidron, \& Limor, 2009). In 2011, the Israeli third sector comprised 34,398 active organizations (Haski-Leventhal, Yogev-Keren, \& Katz, 2012: 18), whose activities focused primarily in the areas of religion (26\%), education and research (19\%), culture and recreation (17\%) and social services (15\%) (Haski-Leventhal, Yogev-Keren, \& Katz, 2012; Limor, 2012). Central Bureau of Statistics data show that the third sector clearly plays an important role in the Israeli economy. Apparently, in addition to its main role - the provision of services that complement or supplement the public sector- the third sector is an important employer in the Israeli market (Haski-Leventhal, Yogev-Keren, \& Katz, 2012: 18).

Indeed, in recent years, NGOs became dominant actors in the Israeli education system (Almog-Bar \& Zychlinski, 2012). In 2007, between 500 and 1,000 external organizations were active in the public educational system, providing activities accounting for nearly $10 \%$ of students' weekly school-schedule (Shiffer, Berkovich, Bar-Yehuda, \& Almog-Bareket, 2010). Weinhaber, Ben Nun, and Schiffman (2008) claim that at least one organization external to the public educational system operates in $89 \%$ of Israeli schools, indicating the high willingness of schools to cooperate with these organizations. 
In 2011, the State Comptroller issued an audit report on "the participation of the third sector and the business sector in the educational system" (State Comptroller, 2011). The report notes that on several occasions in recent years, the Ministry of Education has received detailed information regarding problems arising from the lack of regulation in running external programs at different schools. The report expresses much criticism regarding the Ministry's response, presenting a series of irregularities: lack of an official body that approves the integration of external programs and a formal procedure guiding this certification; lack of awareness of Ministry of Education supervisors regarding the existence of several external programs at the schools they are charged with; and a multitude of external programs operating within the educational system absent any official permission to do so.

The wide and significant involvement of third sector organizations in the education system and the lack of proper supervision by the Ministry of Education aroused an important and complex debate regarding the effects of this involvement on educational and organizational processes that occur within the different schools. Given the context of this debate, Israel is a suitable case for our analysis. Moreover, the Israeli Education Ministry's lack of regulation allows us revealing the impact of NGO activities on different schools. While in a previous study (Authors, 2014), we examined the objectives, nature, and perceived outcomes of school-NGO engagement from the perspective of the involved stakeholders, the purpose of the present research is to develop a deeper understanding of the characteristics and possible consequences of the interaction between third sector organizations and schools from different socioeconomic backgrounds in particular. 


\section{Methodology}

The findings reported in this paper comprise part of a larger mixed-methods research project including participation at school events, meetings, and ceremony observations; in-depth interviews with school principals and Ministry of Education officials; and quantitative surveys of school staff. We rely here only on the findings from our direct investigation related to NGOschool-LEA interaction but bear in mind additional supportive sources of information from the broader research undertaking.

This study is based on qualitative research principles (Miles \& Huberman, 1994) involving data collection through in-depth interviews in a case-study methodology (Yin, 2013). This approach was employed to answer the 'how' and 'why' questions in empirical settings regarding contemporary events. To add to the trustworthiness to our research design, we investigated four units of analysis (Yin, 2002) assessing the same NGO's interactions with two schools catering high-SES and two schools catering low-SES populations. We also interviewed a Local Education Authority (LEA) official, and we collected and analyzed schools' web-site statements, as well as

official documents of the NGO, schools, LEA, and Ministry of Education. While we present the findings based on interviews, these additional documents were used for clarification and triangulation purposes. Notably, we followed Edwards' (2012) protocol by undertaking research on policy production processes that include action across multiple levels (national, local, and school levels) and among multiple types of actors (NGO, LEA, and school staff).

\section{Data collection}

In this part of the research we conducted eleven in-depth interviews with principals and teachers at four primary schools located in one middle-class Israeli city. Based on purposeful sampling (as per Charmaz, 2006) (aimed to focus on high and low SES populations), we 
interviewed the principal and at least one teacher from each school (the teachers who are responsible for the program implementation) (see Table 1), as well as the director of a specific NGO (introduced below) operating at these schools, a professional at the NGO charged with coordinating this interaction, and a LEA representative.

In selecting the four schools in our sample, we obtained data on schools' SES from three independent sources. First, we asked the NGO to characterize the schools within the selected locality. Next, we approached the Israeli Bureau of Statistics and checked the SES index of each of the neighborhoods where the schools are located (attendance at most Israeli public primary schools - and all those in our sample - is neighborhood-based). Finally, we verified the schools' SES with the principals during the interview.

The second author conducted the open-ended interviews (as per Johnson \& Christensen, 2014) at the principals' offices and teachers' lounges within the schools, or at other locations according to the teachers' preferences and convenience. The interviews lasted between one and two hours. All interviews were recorded and transcribed literally shortly after the interview, to enable analysis. All interviews were conducted in Hebrew and later translated to English by a professional translator and re-checked by each of the authors. The open-ended, pre-planned, semi-structured interview questions were intended to reveal the 'how' and 'why' of the NGOs' activity within schools. For example: How did the NGO start to work with the school? What is the rationale for their choice to work with this particular NGO? Who opposed the arrangement? The questions all attempt to allow for a wide array of responses and reflect no judgment. Some questions were added spontaneously within the dynamics of each of the interviews.

The following are descriptions of the interview settings at each of the selected schools: 
School A (high SES): The school is located in a new district of the city, surrounded by new buildings and a population that seems financially well-off. The school grounds are large and spacious, and its facilities are relatively new and very well maintained. The principal received the interviewer in his office, and the interview began as scheduled. The secretary and a student interrupted the interview briefly. In interview, the principal was willing to answer concise questions but did not encourage any dialogue. The interaction was cordial, but the principal spoke with an authoritarian tone and attempted to set the pace and timing of the interview, trying in particular to make sure that the interview would not exceed its allotted timeframe. During the interview, the principal limited his answers to facts and avoided giving personal opinions.

School B (low SES): The school is located in an old area of the city, surrounded by old buildings and a population that seems to be mid-low SES. The school grounds are rather small and relatively old but well maintained. The interviewer was delayed in arriving, and the interview began 45 minutes late. Despite the delay, the interview developed into a dialogue that began with an informal conversation about the interviewer's personal background and that of the principal, and included various topics. The interview was briefly interrupted two or three times by phone calls. The principal expressed no time pressure, so the interview evolved into a lengthy conversation. The principal offered both facts and his personal opinions in relation to the different topics, in quite a free interaction.

School C (high SES): The school is located in one of the oldest neighborhoods in the city, surrounded by large and luxurious houses; it seems to cater to a high-SES population. The school's large, spacious property is comprised of old but very well maintained buildings. The interview took place following two prior cancelations by the school principal. Although the principal had agreed to the interview date and time in advance, she began by stating that the 
timing was inconvenient but that she had agreed to follow through with the interview because she already canceled it twice. She asked that the interview be as quick and concise as possible, stating that she had very little time for it. The interview proceeded with a very practical approach by the principal, in which she was ready to answer concise questions but did not encourage any dialogue.. The interview was conducted without interruption.

School D (low SES): The school is located between an old neighborhood and a new one, surrounded by old and humble houses (and even some caravans), as well large new apartment buildings. The population seems of mid-low SES. The school grounds are large and spacious, with a lot of vegetation surrounding buildings that are quite old but well maintained. The interview proceeded in a form of dialogue that began with an informal conversation about the interviewer's and principal's personal backgrounds and included many tangential topics. It proceeded uninterrupted. The principal expressed no time pressure, so the interview developed into a relatively long one. The principal both discussed facts and offered his personal opinions in a free-flowing interaction.

\section{About the NGO selected for the study and its relation to broader educational trends}

The "Ecologist" (pseudonym) NGO, whose interactions with schools we investigate in this study, was established in 1998 to promote environmental education. Today, it works in collaboration with major Israeli philanthropic agencies and the Israeli government (mostly with the Ministry of Environmental Protection and not with the Ministry of Education), operating environmental sustainability programs in over one hundred schools. The Ecologist's activities include establishing recycling centers in schools, promoting water conservation, composting, establishing school-based organic gardening programs, and initiating local environmental 
campaigns. The organization's website claims that it works with schools from across the socioeconomic spectrum; with Jewish, Arab and Cristian students; and with affluent and marginalized populations nation-wide. We chose to study this particular NGO's interactions with schools given its high visibility in the Israeli education system, its large size, and its long-term existence within the system, as well as due to its activities in different socioeconomic sectors, which was the focus of our study. Moreover, the Ecologist's aims of environmental education correspond with a global educational trend related to global citizenship, human rights, and environmental issues (Authors, 2015).

Notably, environmental education has been integrated into national strategies for sustainability worldwide (Pizmony-Levy, 2011). From the 1970s, the Israeli Ministry of Education began to add environmental issues into traditional school subjects such as sciences, biology, and nature studies. In recent years, substantial efforts and resources have been invested in developing environmental education programs in the Israeli school system (Sagy \& Tal, 2015). Elementary schools in Israel are obligated to teach 'environmental studies' as an integral part of the curriculum, while schools can join environmental networks related to the Ministry of Environmental Protection (Pizmony-Levy, 2011). Nevertheless, schools can custom-tailor their curriculum and their extent of participation in environmental networks in accordance with their own resources combined with the official MOE curricula, absent any external involvement. Pizmony-Levy notes that the decentralization that the Israeli education system underwent in recent decades fostered an "opening up" (p. 620) of schools to external content and probably to external stakeholders as well. 


\section{Data analysis}

Data analysis was performed as detailed in Edwards (2012), based on qualitative data analysis techniques (Miles \& Huberman, 1994) including coding, organizing, and reorganizing the data through development of matrixes and models. To analyze the data, we first completed thematic summaries detailing salient themes from each interview (as per Glaser \& Strauss, 1967). We developed inductive codes based on our initial thematic summaries and deductive codes drawn from the literature. Using matrices and analytic memos, we conducted cross-case analysis to identify emerging themes across data sources (as per Miles \& Huberman, 1994). Our analytic process was iterative and spiral while applying the central steps of coding the data: reducing the data into meaningful segments, combining the codes into broader categories, and displaying the core data (as per Creswell, 2007). Examples of codes generated through the data analysis process: "resistance to NGOs' objectives", "parents involvement", "teachers' role in the process", "activities performed by the school", "attributed benefits and pitfalls for the NGOs' activities". We analyzed the data from the beginning of our data collection process, throughout the entire data collection process, and afterwards (as per Thornberg \& Charmaz, 2014).

\section{Findings}

This study provides an intriguing glimpse into the complex network of goals and power relations between different stakeholders directly and indirectly involved in school-NGO interactions involving schools with students of differing socioeconomic backgrounds. We arrange the findings of this study according to several major themes that emerged during our analysis, thereby highlighting the aims and rationales of each of the involved stakeholders, 
depicting the power relations in such interactions, and discussing how the schools shape their respective environmental education agendas. We show how global socioeconomic tensions are replicated and indigenized in local Israeli schools, where NGOs and the LEA de-facto expropriate the agency from the less affluent schools while more affluent schools maintain full agency in these entrepreneurial ventures. Furthermore, we reveal how each of the stakeholders approaches the interaction with its own aims and interests.

\section{Who has a space for agency within the school?}

A striking disparity that our study reveals relates to how NGO-school interactions involve different and sometimes conflicting aims, which are framed rather differently in schools serving communities of higher and lower socioeconomic status. Different actors pursue their aims to differing extents, but only several stakeholders maintain the ability to act entrepreneurially within this interaction. In this part, we present the power relations between the various agents involved and characterize respective agency each expressed.

Most notable in this regard is the schools' differing agency in their interaction with the NGO. Our interviews revealed that schools serving less affluent communities have a much more restricted choice regarding their engagement with the NGO, facing pressure from the LEA and finding themselves unable to forgo the promise of additional resources that the NGO program offers. Thus, de-facto, they are pushed into the interaction. Indeed, schools experience different levels of autonomy regarding their activities with the NGO, since the NGO's programs are facilitated and partially funded by the LEA - funding that different schools need to varying extents, thus providing the LEA differing degrees of leverage over schools in its quest to engage them in this program. 
As the LEA representative explained, "each year, we present and market the program [to school principals]. We explain to them that we pay almost everything, while schools pay one third (of the total cost) or even less... we show them the benefits." She continued to explain how she engaged a principal from one school serving a less advantaged population: "In the first year it was a bit hard for him to be engaged, so I supported him a lot. We want them to join.”

The LEA's pressure on schools serving less advantaged communities to engage with the NGO also emerged from the statements their principals made during the interviews. For example, the Principal of School B said: "it wasn't really the right time for me to enter the partnership with the NGO... but the LEA placed a lot of pressure on me to engage with the NGO, so I did."

In contrast, school principals of more affluent schools demonstrated autonomy and choice regarding the decision to engage with the NGO, seemingly more powerful in their relationship with the LEA than their colleagues serving less advantaged communities. For example, the LEA representative explained about a school serving a more affluent population: "the last principal was very defensive, wouldn't allow anybody to come near her school... and refused everything." The principal of School A, serving an affluent population, said:

If I think that [an NGO program] fits and is right for the school, and I identify it as a necessity, I take it. If not, I would not engage with the NGO.... You must not be tempted, the entrance of an NGO into school can also cause an earthquake.... They [the LEA] can make recommendations, but I decide whether it is appropriate or inappropriate for the school.

We followed the interesting rationalization dynamics that different stakeholders apply to the apparent differences in school-NGO interaction between schools serving different kinds of populations. When asked directly about these differences (between schools in more and less 
affluent communities) in the initiation, implementation, and institutionalization of the schoolNGO interaction, most of the interviewees denied the existence of such differences and provided universal statements regarding the importance of environment education to all social strata. Nevertheless, several differences in the way socioeconomic status affects this interaction emerged indirectly in the interviews. For example, the NGO perceives schools in less advantaged areas as easier to influence. In the its CEO's words,

It is much easier to make a transformation when you are not in a comfort zone... when you are happy and you have everything, it is harder to move you towards change... and those schools [serving less fortunate populations] are far from the comfort zone.... We work in different localities, both rich and poor. Sometimes the [Environmental Protection] Ministry provides the poor localities with extra funds, so it is even easier for us to get involved and to receive funding there.

In contrast, the LEA representative claimed that schools serving more affluent communities "have a lot of demands... they can say that they are simply not interested [in the program]." Axiomatically perhaps, these perceptions regarding the ease of entrance into a school do not correspond with those of the principals from schools serving communities of lower versus higher socioeconomic status regarding the value of the program to their schools. In fact, school principals from schools in wealthier communities reported a positive change in their school as a result of the NGO's program, while the views of principals from schools in less affluent areas regarding the results of the interaction were rather skeptical and pessimistic. As the principal of School B (serving a low-SES community) explained: "it seems that the priorities are being displaced ... you actually need to compromise." The principal of the other school serving less advantaged students, School D, added: 
You see, there are politics involved. They continue convincing you to accept [the NGO's program]. You can say that this is not a good time, that there are problems with the program, but ultimately it is all politics; sometimes you need to accept this [program] anyway.

Another issue related to agency involves the teachers who are responsible for the program in each of the schools. In each school, a specific teacher is appointed to lead the program. As the person actually responsible for the program's success, all stakeholders provide these teachers with substantial attention. As the LEA representative explained: "We ask the school to appoint an entrepreneurial [successful] teacher.... The teacher has to act according to the NGO's guidance... and to be self-motivated." Occasionally, the LEA (following the NGO's request) urges schools to change the teacher coordinating the program, if the NGO considers the teacher to be functioning inadequately. The NGO representative explained that the organization must "manage these relations ... if the teacher is not engaged, we initiate a discussion with the school ... sometimes changes should be made." This element of the interaction introduces another opportunity for the power dynamics between respective schools and the LEA to play out.

An additional factor affecting the school-NGO interaction is the parents. The parents' role seems particularly important in schools serving students of higher socioeconomic status, as expressed by School A's principal, who claimed that he "took on this program mainly because of the parents." In contrast, School D's principal, who serves a less affluent population, noted that the "parents don't understand the difference between NGO, the LEA, and others. They are happy to get things with added value. That's all. They are not proactive in this process."

An additional interesting difference we found between schools serving communities of different socioeconomic status involved the manner in which the NGO's program was integrated 
into the school curriculum. We found that schools in more affluent areas engage in a planning process prior to entering the program, to engage teachers in it. The principal of School C said:

Usually, when I integrate a program into the school, I think about the organization of the process, of how I can arrange the schedule in advance so the program fits in. I scheduled an hour for green leadership in advance, so she [the teacher responsible for the program] can meet the counselor or the children themselves, and they work together.

As opposed to this high level of organization and advance planning, schools serving less advantaged populations demonstrated a more makeshift attitude towards the program's integration process. In general, lower levels of pre-planning may characterize those schools, resulting from the many constraints of reality and various unexpected problems that arise and must be solved on a daily basis. Thus, a new teacher at School B who is responsible for accompanying the NGO's program said that she "had problems and did not know who to turn to ... I still haven't found my place in this interaction." In contrast, the principal of School C (serving a high-SES population) explained: "each project that we develop at the school is thoroughly planned, we propose deliverables and we follow up on the progress.”

\section{Forcing the green agenda}

Another intriguing finding involves the different aims held by school principals and teachers at schools serving communities of lower versus higher socioeconomic status. The aims of school staff regarding the school-NGO interaction can be depicted as located along a continuum, whereby physical (usually financial) resources are located on one end of the spectrum, whereas other more intangible assets (values, innovation, etc.) are placed at the other end. School leaders 
from schools serving less affluent communities addressed their motivation to interact with the NGO in terms of procuring additional financial resources for the school. As Principal D explained, "we are doing this because they [the NGO] bring additional assets, so I can develop the young leadership program and devote more hours funded by the LEA." The same principal also depicted his school's interaction with the NGO as a compromise, since they actually might have preferred to receive something else (but perhaps lacked other options): "we are paying the price to get the resources. This [environmental program] was not on my agenda, but I ended up engaging in it...although it comes at a price." The same principal continued: "There are things that you do in order to please [the LEA]; yes, certainly, there are things in this context that I do to please, not because I think this is the most fitting agenda." In contrast, the principal of School A (serving a more affluent community) expressed greater confidence in the school's ability to selectively take from the interaction only those elements that the school leadership considers more valuable, claiming that the NGO "cannot sporadically engage with the school, since not everything that they bring I need. We try to select elements that are not mere additional resources but rather are unique and novel ... to add value to the teachers."

Moreover, the same dilemma between accepting any additional resources being offered and more selectively seeking out innovation or added value from the NGO program emerged in the different school principals' descriptions of how the interaction with the NGO is financed. ${ }^{2}$ It seems that in schools serving more affluent communities, even the financial discourse is framed from an 'added value' perspective, as noted in the words of School Principal A: "yes...we need to pay, but this is not the issue; the question is not about the money, but rather about what you are doing with it ... what kind of values you can develop here.” On the other hand, the Principal

\footnotetext{
${ }^{2}$ Schools must participate in funding the programs provided by this NGO (at a rate of approximately $\$ 650$ per year). The LEA matches this budget, and the schools receive several resources like teaching hours and specific facilities through the interaction.
} 
of School B, which serves less advantaged students, noted, "you need to pay, but you gain various resources that are worth more than what you paid for, since the LEA also contributes." Clearly, schools serving less advantaged communities seemed to be less 'picky' about what specifically they are receiving, focusing more on the bottom-line gain: that they receive more than they paid for.

All schools benefited somehow from the interaction with the NGO; nevertheless, the perceived value of a program offering environmental education seemed to be higher in schools serving more advantaged communities. Indeed, the LEA representative described initial challenges in implementing the program at one of the participating schools serving less advantaged populations, where the principal seemed to be engaged with more pressing issues: "I approached [the principal] several times and tried to assist [in implementing this program], but she was busy with other things... she wasn't available for this, I guess she thought it is not that important." The NGO representative stated that this same principal actually explained to him, "I can't deal with environmental issues now, we have other problems: the school is dirty, we don't have enough classes, we have violence problems." the NGO representative concluded that schools serving communities of lower socioeconomic status "tend to perceive our activity as a luxury, although it is not a luxury at all; it is suitable for everybody." Indeed, the principals of both schools serving less affluent populations seemed to concur with this notion. School D's principal said, "the green agenda was sort of forced upon the school. I don't see a real need for it." School B's principal stated, "I do not see how this process holistically permeates into the school."

In contrast, the principals of both schools serving students of higher socioeconomic status were more enthusiastic about the program's perceived value. School A's principal explained: "I 
decided to engage with the NGO for two reasons. First, to bring innovation, which we still don't have here. Second, we can use [the NGO] as an external agent that might see something we miss because we are insiders here." School C's principal said, "you can already see the change here. The children come to school with recycling bags, ... they recycle bottles, they try to arrive by bike. We talk about nutrition, a healthy lifestyle, and all these things." Notably, the traditional claim that NGOs can bring innovation to the 'drowsy' public sector (DeStefano \& Schuh Moore, 2010) seems to be materializing only in more affluent settings, leaving less affluent communities lacking that benefit (at least from the school principals' perspective).

These differences between schools from diverse backgrounds reflect a difference in the discourse between them regarding the outcomes of school-NGO interactions, in which the LEA plays a key role. As the LEA representative put it, "the school says "we want [the NGO program]' or 'we don't want it'; but our goal is to promote this [green agenda through a joint green network] regardless." Thus, while the discourse in schools serving more affluent populations is very optimistic regarding the outcomes of the interaction with the NGO and the resulting adoption of the green agenda it promotes, the discourse among principals serving less advantaged children was found to be skeptical and even pessimistic in this regard.

We further investigated the aims of the NGO and the LEA. It seems that these stakeholders share aligned goals. The LEA's representative noted that "we want all schools in the LEA to be labeled 'green schools' [by the Ministry of Environmental Protection].... We want our city to be green... you cannot deny the branding value of this for us." While the LEA is interested in branding and presenting all schools in the locality as taking part the 'greening' process (an interest promoted by the NGO's program), the NGO seeks to institutionalize its activities, 
thereby benefitting from the governmental budgeting in the long run. The NGO's CEO explained:

Our aim is to transform the education system ... At first we needed to pay schools to let us come in, and now it is the opposite, the schools are paying us... we decided not to act sporadically with different schools but rather to join the system itself through LEAs... We are approaching various LEAs now, so we won't need to convince each school.... It is much easier this way.

The NGO's Regional Coordinator detailed their institutionalization process within schools, explaining that following the first year of activity in any school, they approach the school leadership and inquire whether they would like to continue in the following year. "We perceive this engagement as a long-term process. If the school doesn't want to continue, we do not give up, but rather meet with the principal to understand why and see what we can change."

\section{Discussion}

This study extends the frame of the emerging line of empirical research (for example, Berkovich \& Foldes, 2011; Eden, 2010; Edens \& Gilsinan, 2005; Silova \& Steiner-Khamsi, 2008; Authors, 2014) concerned with the attempts to empirically characterize and conceptualize the growing involvement of external agencies and in particular NGOs in education and particularly in schools. Employing a qualitative methodology, we interviewed different stakeholders in a NGO-school-LEA interaction, including school principals, involved teachers, the LEA representative, and the NGO's CEO and Regional Coordinator. We chose to focus our study on one very heterogeneous Israeli locality where NGO involvement in education is neither 
regulated nor monitored; there, we approached schools serving both lower- and upper-middle class communities. Our study contributes to the knowledge in this field further by providing actual empirical foundations to the sociological debate on the influence of the growing NGO presence in the public education system not only grounded in the developed vs. developing countries discourse, but rather within the same country, even same locality.

The focus of our study on the education system in Israel - a country with a per capita GDP of $\$ 36,050$ and a developed high-tech sector - allowed us to further conceptualize the NGO-school interaction that has formerly been depicted in low-income countries (Edwards, 2014; Rappleye, 2011). In line with Feuerstein's (2001) findings regarding commercial organizations' involvement in schools from different backgrounds in the US and Miraftab's (2004) conclusions regarding the private-public partnership as a 'Trojan horse' in low-income countries' development, here we uncover how communities' socioeconomic status shape the school-NGO interaction within a given educational setting. We also present the power relations involved in imposing the environmental agenda (Pizmony-Levy, 2011) on different local settings with different needs and wants, allowing a glimpse into the respective agency of the involved stakeholders.

We found that school-NGO-LEA interaction seems to operate within the existing power relations between different agents, whereby the ability to express agency and to access resources depends on the relative strengths of each party involved. The tension mainly revolves around the triangle of the schools' need for autonomy, the LEA's need for branding (promoted by belonging to a governmentally-authorized network of 'green schools'), and the NGO's need for institutionalization (which helps guarantee the program's future existence and funding, as discussed by Authors [2014]). We examined how schools serving communities of different 
classes manage their relations within this triangle and how the lesser autonomy of schools serving less affluent populations (in particular, their need to recruit more resources) shapes those relations in comparison to schools serving more affluent communities. As was shown in other studies regarding Nepal (Rappleye, 2011), El Salvador (Edwards, 2014), and Post-Soviet republics (Silova \& Steiner-Khamsi, 2008), NGOs import and impose their (global) agenda on the local reality with questionable adaptation to the local needs. Edwards (2014) showed how governmental funding was used to encourage communities to cooperate with NGOs, forcing them to change their agenda and even work (hire and fire) with teachers that haven't worked in the communities before. While Edwards (2014) is following the role of intergovernmental organizations in conflict ridden areas, claiming that global education policies are effectively and undisturbedly promoted through NGOs, utilizing "blind spot" (p. 411) where NGOs can freely promote their policies, we provide a novel view regarding this discourse, empirically showing how the global (environmentally-oriented) policy is shaped and implemented within one national setting (Israel) in specific educational context. Moreover, we emphasize the role of the local regulatory agent (the LEA) in this process as a chaperone fostering NGOs' goals in its own interest. In this case, the NGO and LEA act in a collaborative (Eden, 2002) and even symbiotic mode, while schools are left to their own agency (according to their own respective assets), and thus public education is shaped and re-shaped by external needs (Kamat, 2004). The uniqueness of the current empirical contribution lies in its comparative nature, providing a detail account of the chronology of such interactions in high and low SES locations, thus directly contributing to the theoretical discourse on the possible implications of growing NGOs' involvement in public schooling. 
Ironically, it seems that the tax payers' money passes from parental pockets (through schools that are funded by the government and the LEAs) to the pockets of the NGO, in exchange for the latter's provision of certain services and resources to schools (as enabled by decentralization), while another governmental agent - the Ministry of Environmental Protection - serves as a gatekeeper in this process, offering authorization of 'green school' status that is exploited to justify the NGO's activities within schools. Thus, the third sector role in those settings can be imagined as a transplanted organ that chaperones the connections between different public spheres - namely, the schools, the LEA, and the Ministry of Environmental Protection; by virtue of its existence, it becomes an irreplaceable (institutionalized) organ, through which the blood metaphorically flows between different organs. While Kamat (2004) is suggesting that NGOs' role should be conceptualized by restructuring the interference between the public good and the private interest, we show how de-facto the better-off communities in the same locality can benefit from such interactions with NGOs, while private agendas (of LEA, NGO and affluent communities) are interfering within the public schooling. Moreover, the specific agenda of NGOs (in our case environmental issues), can be imposed on schools without proper investigation of the specific need of such agenda, thus adding more external interference and thus also disturbance to schools' functioning, especially in more vulnerable loci. The public schooling in this context is shaped according to the array of diverse and conflicting private interests, that of LEA, NGOs and affluent communities.

To conclude, within the lively discussion in the literature highlighting the risks of increasing social inequality as a result of NGO involvement in the education system, this study provides a fascinating glimpse into the differences between the goals and aims, power relations, and processes of integration of an NGO's program within schools serving communities of different 
classes. These differences should be further examined within the context of socioeconomic status' impact on education. 


\section{Bibliography}

Almog-Bar, M., \& Zychlinski, E. (2012). A Façade of Collaboration: Relationships between philanthropic foundations and the government in social policy-making in Israel. Public Management Review, 14(6), 795-814.

Arnove, R. F. (2009). World-Systems Analysis and Comparative Education in an Age of Globalization. International Handbook of Comparative Education, In R. Cowen and A. M. Kazamias (Eds.), New York: Springer.

Arnove, R. F., \& Christina, R. (1998). NGO-state relations: An argument in favor of the state and complementarity of efforts. Current Issues in Comparative Education, 1(1), 1-5.

Authors (2014)

Authors (2015)

Authors (2016)

Ball, S. J. (2009). Privatising education, privatising education policy, privatising educational research: Network governance and the 'competition state'. Journal of Education Policy, 24(1), 83-99.

Ball, S. J. (2007). Education plc: Understanding private sector participation in public sector education. London: Routledge.

Berkovich, I., \& Foldes, V. (2012). Third sector involvement in public education: the Israeli case. Journal of Educational Administration, 50(2), 173-187.

Boli, J., \& Thomas, G. M. (1999). Constructing world culture: International nongovernmental organizations since 1875. Stanford: Stanford University Press. 
Bulkley, K. E., \& Burch, P. (2011). The Changing Nature of Private Engagement in Public Education: For-Profit and Nonprofit Organizations and Educational Reform. Peabody Journal of Education, 86(3), 236-251.

Burch, P. (2006). The New Educational Privatization: Educational Contracting and High Stakes Accountability. Teachers College Record, 108(12), 2582-2610.

Carnoy, M., \& Rhoten, D. (2002). What does globalization mean for educational change? A comparative approach. Comparative Education Review, 46(1), 1-9.

Charmaz, K. (2006). Constructing Grounded Theory: A Practical Guide Through Qualitative Analysis. London: Sage.

DeStefano, J., \& Schuh Moore, A.M. (2010). The roles of non-state providers in ten complementary education programmes. Development in Practice, 20(4-5), 511-526.

Drori, G. S., Meyer, J. W., \& Hwang, H. (2006). Globalization and organization: World society and organizational change. Oxford: Oxford University Press.

Dyer, C., \& Rose, P. (2005). Decentralisation for educational development? An editorial introduction. Compare: A Journal of Comparative Education, 35 (2), 105-113.

Eden, D. (2012). 'Whose responsibility is it?': The third sector and the educational system in Israel. International Review of Education, 58(1), 35-54.

Edens, R., \& Gilsinan, J. F. (2005). Rethinking school partnerships. Education and Urban society, 37(2), 123-138.

Edwards, Jr, D. B. (2012). Researching international processes of education policy formation: Conceptual and methodological considerations. Research in Comparative and International Education, 7(2), 127-145. 
Edwards Jr, D. B. (2014). Rising from the ashes: how the global education policy of community-based management was born from El Salvador's civil war. Globalisation, Societies and Education, (ahead-of-print), 1-22.

Edwards Jr, D. B., \& De-Matthews, D. (2014). Historical trends in educational decentralization in the United States and developing countries: A periodization and comparison in the post-WWII context. Education Policy Analysis Archives, 22(40), 2-38.

Edwards, M., \& Hulme, D. (1995). NGO performance and accountability in the post-cold war world. Journal of International Development, 7(6), 849-856.

Eikenberry, A. M., \& Kluver, J. (2004). The Marketization of the Nonprofit Sector: Civil Society at Risk?. Public Administration Review, 64(2), 132-140.

Feuerstein, A. (2001). Selling our schools? Principals views on schoolhouse commercialism and school-business interactions. Educational Administration Quarterly, 37(3), 322-371.

Gidron, B., Bar, M., \& Katz, H. (2004), The Israeli Third Sector: Between Welfare State and Civil Society. New York: Kluwer Academic.

Ginsburg, M. (2008). Bridge over Black [ened] Water: A New Refrain for NGOs. Current Issues in Comparative Education, 10, 6-9.

Haski-Leventhal, D., Yogev-Keren, H. and Katz, H. (2012). The Israeli Third Sector Workforce 2000-2009. Beersheba: Ben-Gurion University, Israeli Center for Third-sector Research. (Hebrew)

Haugh, H., \& Kitson, M. (2007). The Third Way and the third sector: New Labour's economic policy and the social economy. Cambridge Journal of Economics, 31(6), 973-994. 
Hoff, L., \& Hickling-Hudson, A. (2011). The role of International Non-Governmental Organisations in promoting adult education for social change: A research agenda. International Journal of Educational Development, 31(2), 187-195.

Johnson, B., \& Christensen, L. (2014). Educational research: Quantitative, qualitative, and mixed approaches. London: Sage.

Ilon, L. (2008). The Growing Market for NGO Influence. Current Issues in Comparative Education, 10, 16-21.

Kamat, S. (2004). The privatization of public interest: theorizing NGO discourse in a neoliberal era. Review of International Political Economy, 11(1), 155-176.

Katz, H., Gidron, B., \& Limor, N. (2009). The third sector in Israel - Characteristics, structure and policies towards it. Civil Review, 6(3), 1-25.

Klees, S. J. (2008). NGOs, Civil Society, and Development: Is There a Third Way? Current Issues in Comparative Education, 10, 22-25.

Limor, N. (2012). Israel NGOs Annual Report: Data Summary. NPtech - Third Sector Technology Ltd. (PBC). (Hebrew)

Miles, M. B., \& Huberman, A. M. (1994). Qualitative data analysis: An expanded sourcebook. Beverly Hills: Sage Publications.

Miraftab, F. (2004). Public-Private Partnerships The Trojan Horse of Neoliberal Development?. Journal of Planning Education and Research, 24(1), 89-101.

Mundy, K., \& Murphy, L. (2001). Transnational advocacy, global civil society? Emerging evidence from the field of education. Comparative education review, 45(1), 85-126.

Nir, A., \& Miran, M. (2006). The equity consequences of school-based management. International Journal of Educational Management, 20(2), 116-126. 
Pizmony-Levy, O. (2011). Bridging the global and local in understanding curricula scripts: The case of environmental education. Comparative Education Review, 55(4), 600-633.

Rappleye, J. (2011). Catalysing educational development or institutionalising external influence? Donors, civil society and educational policy formation in Nepal. Globalisation, Societies and Education, 9(1), 27-49.

Resnik, J. (2011). The construction of a managerial education discourse and the involvement of philanthropic entrepreneurs: the case of Israel. Critical Studies in Education, 52(3), 251-266.

Robertson, S., Mundy, K., \& Verger, A. (Eds.). (2012). Public private partnerships in education: new actors and modes of governance in a globalizing world. Cheltenham: Edward Elgar Publishing.

Rose, P. (2009). NGO provision of basic education: alternative or complementary service delivery to support access to the excluded? Compare: A Journal of Comparative \& International Education, 39(2), 219-233.

Rose, P. (2010). Achieving Education for All through public-private partnerships?Development in Practice, 20(4-5), 473-483.

Sagy, G., \& Tal, A. (2015). Greening the Curriculum: Current Trends in Environmental Education in Israel's Public Schools. Israel studies, 20(1), 57-85.

Shiffer, V., Berkovich, I., Bar-Yehuda, S., Almog-Bareket, G. (2010). Third Sector Organizations Involvement in the Educational System. Van Leer Institution, Mandel Leadership Institute (Hebrew).

Silova, I., \& Steiner-Khamsi, G. (2008). How NGOs react: Globalization and education reform in the Caucasus, Central Asia and Mongolia. Bloomfield, ST: Kumarian Press.

State Comptroller, 2011, Annual Report 62 (2011) (Hebrew) 
Stromquist, N. P. (2008). Revisiting transformational NGOs in the context of contemporary society. Current Issues in Comparative Education, 10, 41-45.

Suárez, D. (2007). Education professionals and the construction of human rights education. Comparative Education Review, 51(1), 48-70.

Unerman, J., \& O'Dwyer, B. (2006). On James Bond and the importance of NGO accountability. Accounting, Auditing \& Accountability Journal, 19(3), 305-318.

Verger, A., Edwards Jr, D. B., \& Altinyelken, H. K. (2014). Learning from all? The World Bank, aid agencies and the construction of hegemony in education for development. Comparative Education, 50(4), 381-399.

Weinhaber, B.C., Ben Nun, R., Shiffman, E. (2008). Involvement of NGOs, Funds and Commercial Philanthropy in the Education System - Findinds' Report: Beit Berl College (Hebrew).

Woods, P., \& Woods, G. (2004). Modernizing leadership through private participation: a marriage of inconvenience with public ethos?. Journal of Education Policy, 19(6), 643-672.

Yin, R. K. (2013). Case study research: Design and methods. London: Sage publications. 
Table 1. Interviewee Details

\begin{tabular}{|c|c|c|}
\hline Interviewees & $\begin{array}{l}\text { Interviewees' } \\
\text { organizational or } \\
\text { institutional affiliation }\end{array}$ & $\begin{array}{l}\text { Description of the } \\
\text { interviewees' roles }\end{array}$ \\
\hline $\begin{array}{l}\text { Local Education Authority } \\
\text { (LEA) representative - } \\
\text { Director of Municipal } \\
\text { Environmental Education } \\
\text { Department }\end{array}$ & $\begin{array}{l}\text { A middle-class municipality } \\
\text { in Israel }\end{array}$ & $\begin{array}{l}\text { In charge of environmental } \\
\text { education at the } \\
\text { municipality. Leads the } \\
\text { interaction with schools in } \\
\text { the field. }\end{array}$ \\
\hline $\begin{array}{l}\text { CEO of the non- } \\
\text { governmental organization } \\
\text { (NGO) "The Ecologist" }\end{array}$ & $\begin{array}{l}\text { An NGO that conducts an } \\
\text { environmental sustainability } \\
\text { educational program at all } \\
\text { schools in this study }\end{array}$ & $\begin{array}{l}\text { Responsible for all activities } \\
\text { of the NGO. }\end{array}$ \\
\hline $\begin{array}{l}\text { Regional Coordinator of the } \\
\text { NGO }\end{array}$ & Part of the same NGO & $\begin{array}{l}\text { In charge of the NGO } \\
\text { activities in this specific } \\
\text { municipality. Leads the } \\
\text { NGO interaction with the } \\
\text { specific schools involved in } \\
\text { the study. }\end{array}$ \\
\hline Principal - School A & $\begin{array}{l}\text { A school serving middle- } \\
\text { high SES areas }\end{array}$ & $\begin{array}{l}\text { Second year as the school } \\
\text { principal. Brought in the } \\
\text { NGO program in the } \\
\text { second half of the } 2014- \\
2015 \text { school year. }\end{array}$ \\
\hline Leading Teacher - School A & Part of the same school & $\begin{array}{l}\text { Led the program since its } \\
\text { entrance into the school. }\end{array}$ \\
\hline Principal - School B & $\begin{array}{l}\text { A school serving middle-low } \\
\text { SES areas }\end{array}$ & $\begin{array}{l}\text { Third year as principal. The } \\
\text { program was already being } \\
\text { implemented when he } \\
\text { entered the school. }\end{array}$ \\
\hline Leading Teacher - School B & Part of the same school & $\begin{array}{l}\text { Has been leading the } \\
\text { program since the } \\
\text { beginning of this school } \\
\text { year. }\end{array}$ \\
\hline Principal - School C & $\begin{array}{l}\text { A school serving high SES } \\
\text { areas }\end{array}$ & $\begin{array}{l}\text { Ninth year as principal. The } \\
\text { program was already } \\
\text { implemented when she } \\
\text { entered the school. }\end{array}$ \\
\hline Leading Teacher - School C & Part of the same school & $\begin{array}{l}\text { Has been leading the } \\
\text { program since it } \\
\text { commenced at the school. }\end{array}$ \\
\hline
\end{tabular}




\begin{tabular}{lll}
\hline Principal - School D & $\begin{array}{l}\text { A school serving middle-low } \\
\text { SES areas }\end{array}$ & $\begin{array}{l}\text { Second year as principal. } \\
\text { The program was already } \\
\text { implemented when he } \\
\text { entered the school. }\end{array}$ \\
Leading Teacher - School D Part of the same school & $\begin{array}{l}\text { Has been leading the } \\
\text { program for the past three } \\
\text { years, since the former } \\
\text { principal introduced it at the } \\
\text { school. }\end{array}$ \\
\hline
\end{tabular}

